\title{
High proportion of cattle and sheep seropositive and renal carriers of Leptospira sp. under semiarid conditions*
}

\section{Alta proporção de bovinos e ovinos soropositivos e portadores renais de Leptospira sp. em condições semiáridas}

\author{
Carla Lauise Rodrigues Menezes Pimenta, ${ }^{* *}$ Denise Batista Nogueira, ${ }^{* *}$ Camila de Sousa Bezerra, ${ }^{* *}$ Davidianne Andrade Morais, ${ }^{* *}$ \\ Maria Luana Cristiny Rodrigues Silva, ${ }^{* *}$ Diego Figueiredo da Costa, ${ }^{* *}$ Severino Silvano dos Santos Higino, ${ }^{* *}$ \\ Carolina Sousa Américo Batista Santos, ${ }^{* *}$ Clebert José Alves, ${ }^{* *}$ Sérgio Santos de Azevedo**
}

\begin{abstract}
The aims of this study were to perform serological and molecular detection of Leptospira sp. infection in cattle and sheep under semiarid conditions. Based on a preliminary study performed in our research group, we selected six rural properties showing a positivity $\geq 60 \%$ for Sejroe serogroup with titer $\geq 200$ measured in serological tests from cattle. In the present study, blood and urine samples were collected from 99 females of reproductive age (51 cattle and 48 sheep) for serological diagnosis, molecular detection and Leptospira sp. attempt to strain recovery. Of the 99 analyzed animals $38.4 \%$ (38/99) were positively reactive at the serological tests. Of them, $49 \%(25 / 51)$ were cattle and $27.1 \%(13 / 48)$ sheep. The serogroups detected in cattle were Sejroe (36.8\%), Hebdomadis (26.3\%), Australis (10.5\%), Djasiman (10.5\%), Ballum (5.3\%), Pomona (5.3\%), and Cynopteri (5.3\%) with titers of 100-800. In sheep, the reactive serogroups were Australis (27.3\%), Ballum (27.3\%), Djasiman (18.1\%), Tarassovi (9.1\%), Icterohaemorrhagiae (9.1\%), and Cynopteri (9.1\%) with titers of 100-400. Leptospiral DNA was detected in nine urine samples, including five cattle and four sheep. Property 1 showed the highest serological positivity frequencies for both cattle (70.6\%) and sheep (70.6\%). Similarly, the highest frequency of DNA detection was also found (eight samples, $89 \%$ ). In this property, we observed the existence of consorted rearing of cattle and sheep with close coexistence between these species. In semiarid conditions, transmission among animals of the same species seems to be the main form of Leptospira sp. dissemination in cattle and sheep herds. However, the contribution of other domestic and wild animals cannot be discarded. The practice of consorted rearing of cattle and sheep and their close coexistence may facilitate the spread of the pathogen in rural properties.
\end{abstract}

Keywords: Animal leptospirosis, consortia breeding, molecular detection, ruminants, semiarid conditions.

\section{Resumo}

Os objetivos deste estudo foram realizar detecção sorológica e molecular da infecção por Leptospira sp. em bovinos e ovinos em condições semiáridas. Com base em estudo preliminar realizado em nosso grupo de pesquisa, foram selecionadas seis propriedades rurais com soropositividade $\geq 60 \%$ para o sorogrupo Sejroe com título $\geq 200$ em bovinos. No presente estudo, amostras de sangue e urina foram coletadas de 99 fêmeas em idade reprodutiva (51 bovinos e 48 ovinos) para diagnóstico sorológico, detecção molecular e tentativa de recuperação de estirpesde Leptospira sp. Dos 99 animais analisados, 38,4\% (38/99) foram sororeativos nos testes sorológicos. Destes, 49\% (25/51) eram bovinos e 27,1\% (13/48) ovinos. Os sorogrupos detectados em bovinos foram Sejroe (36,8\%), Hebdomadis (26,3\%), Australis (10,5\%), Djasiman (10,5\%), Ballum (5,3\%), Pomona (5,3\%) e Cynopteri (5,3\%) com títulos de 100 a 800 . Nos ovinos, os sorogrupos reativos foram Australis (27,3\%), Ballum (27,3\%), Djasiman (18,1\%), Tarassovi $(9,1 \%)$, Icterohaemorrhagiae $(9,1 \%)$ e Cynopteri $(9,1 \%)$ com títulos de $100-400$. O DNA leptospiral foi detectado em nove amostras de urina, incluindo cinco bovinos e quatro ovinos. A propriedade 1 apresentou as maiores frequências de positividade sorológica para bovinos $(70,6 \%)$ e ovinos $(70,6 \%)$. Da mesma forma, a maior frequência de detecção de DNA também foi encontrada (oito amostras, $89 \%$ ). Nesta propriedade observou-se a existência de criação consorciada de bovinos e ovinos com estreita convivência entre estas espécies. Em condições semiáridas, a transmissão entre animais da mesma espécie parece ser a principal forma de disseminação de Leptospira sp. em rebanhos bovinos e ovinos. No entanto, a contribuição de outros animais domésticos e selvagens não pode ser descartada. A prática de criação consorciada de bovinos e ovinos e sua estreita convivência podem facilitar a disseminação do patógeno em propriedades rurais.

Palavras-chave: Leptospirose animal, criação consorciada, detecção molecular, ruminantes, condições semiáridas.

*Recebido em 21 de agosto de 2019 e aceito em 2 de março de 2020.

**Universidade Federal de Campina Grande (UFCG), Centro de Saúde e Tecnologia Rural (CSTR), Av. Universitária, s/n, Santa Cecília, Patos, PB 58708-110, Brazil.

Corresponding author. E-mail: sergio@vps.fmvz.usp. (S.S. Azevedo). 


\section{Introduction}

The development of cattle and sheep farming is of paramount importance for Brazilian agriculture and livestock in addition to contributing to the income of rural producers (CAMPOS et al., 2017). Leptospirosis, one of the most important infectious diseases in cattle and sheep production, is caused by bacteria of the genus Leptospira sp. and stands out as causing serious reproductive problems such as abortions, birth of weak animals, stillbirth, and fetal mummification in addition to reduced milk production, which causes substantial economic losses to cattle and sheep industry (ELLIS, 2015; LOUREIRO et al., 2017).

Under natural conditions, any Leptospira sp. serogroup can affect any animal species. However, some animals might adapt to certain strains. Cattle are recognized as adapted hosts of the Sejroe serogroup, which is reported in $>80 \%$ of studies in Latin America (PINTO et al., 2016). Hardjo is the most common serovar in cattle worldwide (HERNÁNDEZ-RODRÍGUEZ et al., 2011; PINTO et al., 2017). This adaptation favors maintaining the bacteria in the environment since bovines act as sources of infection for their own and other animal species (MUGHINIGRAS et al., 2014). Leptospira sp. infection in sheep has been commonly associated with the serogroup Hardjo, also adapted to small ruminants, and the serogroup Autumnalis (HIGINO et al., 2013; MARTINS; LILENBAUM, 2014).

Northeastern Brazil is characterized by a semiarid climate with low rainfall and high temperatures. The state of Paraíba, located in the Northeastern region of Brazil, is characterized by warm weather throughout the year. The state is geographically subdivided into the following four major regions, based mostly on vegetation type and rainfall: (i) Zona da Mata (Atlantic forest), (ii) Agreste, (iii) Borborema, and (iv) Sertão. The Zona da Mata and Agreste have relatively higher rainfall regimes. Both Borborema and Sertão (the semiarid region) are typically within the Caatinga biome, which encompasses an area of $900,000 \mathrm{~km}^{2}$ (11\% of Brazilian territory) and is the only major biome that occurs exclusively in Brazil. Caatinga is xeric shrubland and thorn forest, which consists primarily of small thorny trees that shed their leaves seasonally. Cacti, thick-stemmed plants, thorny brush and arid-adapted grasses make up the ground layer. However, during the dry periods there is no ground foliage or undergrowth (ANDRADE-LIMA, 1981). The weather is characterized by a hot and semiarid climate, with temperatures averaging $27 \circ \mathrm{C}$, and the mean annual rainfall is typically $\approx 500 \mathrm{~mm}$. There are typically two seasons: a rainy season from February to May, and a long drought period from June to January. However, occurrences of droughts sometimes lasting for longer than one year is also a characteristic of the region (BATISTA et al., 2007).

These conditions, associated with the characteristics of Caatinga, plant formation in this region, and a unique biome that is exclusively Brazilian and presents a wide diversity of animal species (PEREIRA JUNIOR et al., 2014), offer unique epidemiological conditions that require consideration in circumstances different from those of other regions of Brazil and the world. Because of this, these particularities should be analyzed in conjunction with the epidemiology of leptospirosis. Studies in the semiarid region (HIGINO et al., 2010; ALVES et al., 2012; COSTA et al., 2016; SILVA et al., 2018; PIMENTA et al., 2019) have shown that even during long periods of drought, the disease has remarkable frequency in the herds of the region. This leads us to highlight the role of adapted infections, in which their agent uses alternative direct transmission pathways and thus suffer less interference from environmental adversities (MARTINS; LILENBAUM, 2015; ELLIS, 2015).

Thus, the aim of this study was to perform serological and molecular detection of Leptospira sp. infection in cattle and sheep under semiarid conditions in Northeastern Brazil, in addition to the bacteriological culture for the attempt of strain recovery.

\section{Material and methods}

Based on preliminary study performed by our research group (PIMENTA et al., 2014), we selected six rural properties presenting $\geq 60 \%$ seropositivity for the serogroup Sejroe with antibody titers $\geq 200$. These properties were located in the municipalities of Boa Ventura (Property 1), Malta (Property 2), Olho d'Água (Property 3), Piancó (Property 4), Quixaba (Property $5)$, and Santana dos Garrotes (Property 6) in the mesoregion of Sertão (Figure 1). For the present study, we selected a total of 99 animals (51 cattle, 48 sheep), all females in reproductive age. None were vaccinated against leptospirosis. Properties 1 , 2, 3, and 6 had cattle and sheep, while Properties 4 and 5 had cattle only.

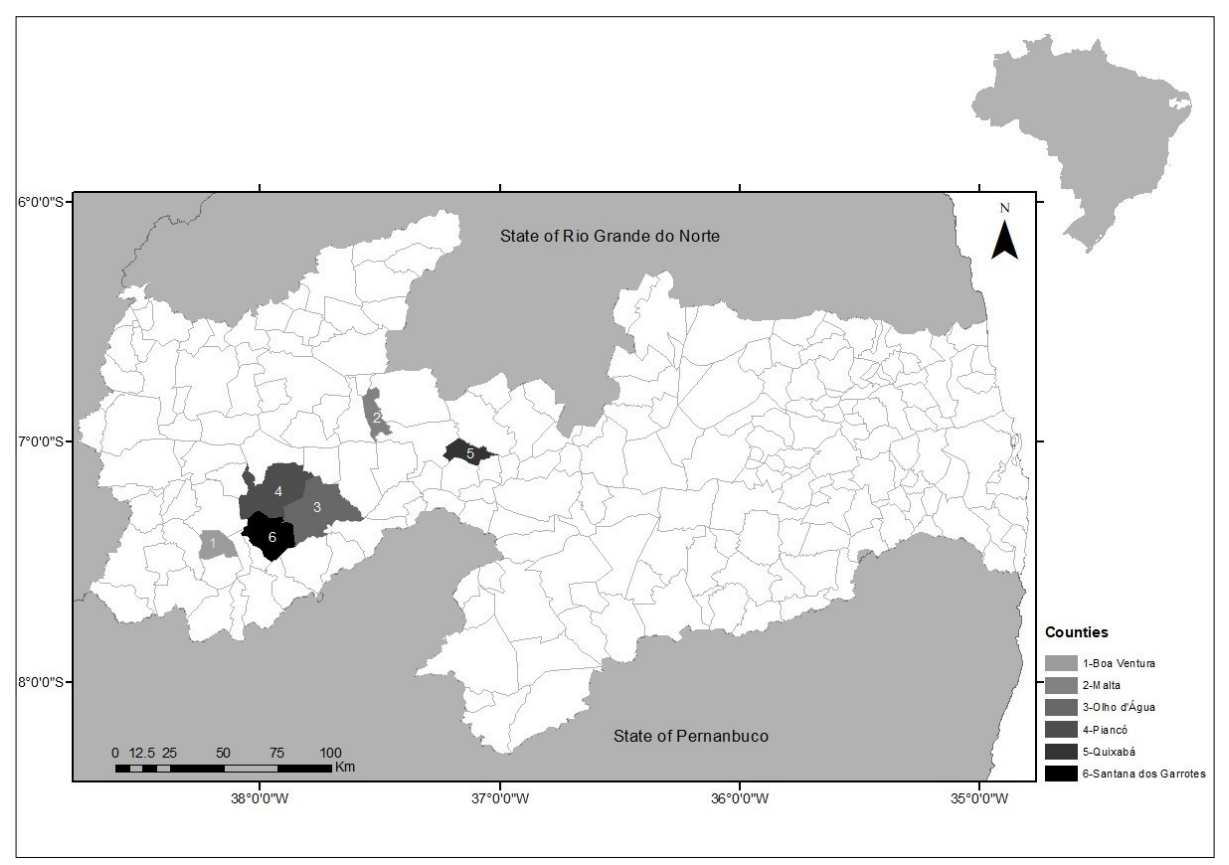

Figure 1: Map of the State of Paraíba with the studied counties. Detail shows the Paraíba State within Brazil. 
Sample collections were performed from July to August 2015, and the average precipitation level of the municipalities was $44.2 \mathrm{~mm}$ ( $\min =0.0 \mathrm{~mm} ; \max =252.4 \mathrm{~mm}$ ). Blood samples were collected by jugular vein puncture in 10-mL vacuum tubes with the aim of subsequently obtaining serum upon centrifugation. The samples were then stored at $-20^{\circ} \mathrm{C}$ until serological testing. In cattle, urine samples were collected using diuretic furosemide (MSD Animal Health, São Paulo, SP, Brazil) at a dose of $2.5 \mathrm{~mL} /$ animal intramuscularly. In sheep, urine samples were collected with a urethral probe no. 8 through $10-\mathrm{mL}$ sterile disposable syringes. For the molecular analyses, urine samples $(2 \mathrm{~mL})$ were aliquoted into microtubes containing $100 \mu \mathrm{L}$ of 10x phosphate buffered saline. The samples were immediately refrigerated and transported within a maximum of 2 hours to the laboratory and stored at $-20^{\circ} \mathrm{C}$ until DNA extraction.

A serological diagnosis of leptospirosis was made using the Microscopic Agglutination Test (MAT), as recommended by the World Organization for Animal Health (OIE, 2014). The serum samples were screened for antibodies against a battery of 24 serovars: Australis, Bratislava, Autumnalis, Butembo, Castellonis, Bataviae, Canicola, Whitcombi, Cynopteri, Grippotyphosa, Hebdomadis, Copenhageni, Icterohaemorrhagiae, Javanica, Panamá, Pomona, Pyrogenes, Hardjo, Wolffi, Shermani, Tarassovi, Andamana, Patoc e Sentot. Sera with $50 \%$ or more agglutination at the indicated dilution were titrated in several two-fold geometric dilutions. The serum titer was the reciprocal of the highest dilution that presented a positive result.

Immediately after collection, $1 \mathrm{~mL}$ of urine was inoculated in a final concentration of $10 \%$ in semisolid EMJH medium (Difco, BD Franklin Lakes, NJ, USA) supplemented with amphotericin B $(0.05 \mathrm{mg} / \mathrm{mL}), 5$-fluorouracil $(1 \mathrm{mg} / \mathrm{mL})$, fosfomycin $(4 \mathrm{mg} /$ $\mathrm{mL})$, trimethoprim $(0.2 \mathrm{mg} / \mathrm{mL})$, and sulfamethoxazole $(0.4 \mathrm{mg} /$ $\mathrm{mL}$ ) to inhibit the proliferation of contaminating microorganisms (CHAKRABORTY et al., 2011). After 24 hours, $1 \mathrm{~mL}$ was inoculated in the semisolid EMJH medium supplemented only with 5 -fluorouracil $(1 \mathrm{mg} / \mathrm{mL})$ in a proportion of $10 \%$ and subsequently incubated at $30^{\circ} \mathrm{C}$. The tubes were examined weekly by microscopy with the samples in a dark field to evaluate the growth of microorganisms with Leptospira-like morphology over a period of at least 12 weeks (Miraglia et al., 2003).

DNA from Leptospira sp. was extracted using the Wizard $^{\circledR}$ Genomic SV DNA Purification System Kit (Promega ${ }^{\circledR}$, Madison, USA). PCR was performed as previously described (STODDARD et al., 2009). The primers LipL 32-45F (5'-AAG CAT TAC CGC TTG TGG TG-3 ') and LipL 32-286R (5'-GAA CTC CCA TTT CAG CGA TT-3'), designed by Stoddard et al. (2009) to amplify the LipL32 gene from pathogenic leptospires, were used. The Pomona serogroup strain and ultrapure water were used as positive and negative controls, respectively.

The chi-square or Fisher's exact test were used to compare the positivity ratios in MAT and PCR between cattle and sheep. The analyses were performed using the BioEstat 5.03 program (AYRES et al., 2007) considering a significance level of 0.05 .

\section{Results and Discussion}

Of the 99 analyzed animals, 38.4\% (38/99) were reactive at the serological test, being $49 \%$ (25/51) in cattle and $27.1 \%(13 / 48)$ in sheep $(P=0.042)$. The proportions of PCR-positivity in cattle and sheep were $9.8 \%(5 / 51)$ and $8.3 \%(4 / 48)$, respectively $(P=$ $0.206)$. Property 1 presented the highest seropositivity for cattle $(70.6 \%)$ and sheep $(70.6 \%)$ (Table 1$)$, as well as the highest PCRpositivity for both cattle and sheep (23.5\%). It was not possible to isolate viable leptospires from any urine sample.

Serological and PCR-positivity frequency for cattle and sheep under semiarid conditions in Northeastern Brazil according to property

\begin{tabular}{llllll}
$\begin{array}{l}\text { Total number of } \\
\text { animals }\end{array}$ & \multicolumn{2}{c}{ Seropositive } & \multicolumn{2}{c}{ PCR-positive } \\
\hline Cattle & Sheep & Cattle (\%) & Sheep (\%) & Cattle (\%) & Sheep (\%) \\
\hline 17 & 17 & $12(70.6)$ & $12(70.6)$ & $4(23.5)$ & $4(23.5)$ \\
7 & 9 & $4(57.1)$ & $1(11.1)$ & $0(0)$ & $0(0)$ \\
3 & 17 & $1(33)$ & $0(0)$ & $0(0)$ & $0(0)$ \\
5 & $\ldots$ & $1(20)$ & $\ldots$ & $0(0)$ & $\ldots$ \\
13 & $\ldots$ & $4(30.8)$ & $\ldots$ & $0(0)$ & $\ldots$ \\
6 & 5 & $3(50)$ & $0(0)$ & $1(16.7)$ & $0(0)$ \\
\hline 51 & 48 & $25(49)$ & $13(27.1)$ & $5(9.8)$ & $4(8.3)$ \\
\hline
\end{tabular}

In Property 1, cattle showed positive reactions to Hebdomadis, Sejroe, Djasiman, Australis, Ballum, and Cynopteri serogroups, while sheep showed positive reactions to Australis, Ballum, Djasiman, Cynopteri, Tarassovi, and Hebdomadis serogroups. In Property 2, it was found a reaction to Sejroe and Icterohaemorrhagiae serogroups in cattle and sheep, respectively. In Properties 3 to 6 , there were reactions against Sejroe, Pomona, and Hebdomadis serogroups in cattle (Table 2).

Table 2: Leptospira sp. serogroups in cattle and sheep under semiarid conditions in Northeastern Brazil, according to property

\begin{tabular}{|c|c|c|}
\hline Property & $\begin{array}{c}\text { Serogroups found in cattle } \\
(\%)\end{array}$ & $\begin{array}{l}\text { Serogroups found in sheep } \\
(\%)\end{array}$ \\
\hline 1 & $\begin{array}{l}\text { Hebdomadis }(25 \%) \\
\text { Sejroe }(25 \%) ; \\
\text { Djasiman }(16.6 \%) ; \\
\text { Australis }(16.6 \%) ; \\
\text { Ballum }(8.4 \%) ; \\
\text { Cynopteri }(8.4 \%)\end{array}$ & $\begin{array}{l}\text { Australis }(30 \%) ; \\
\text { Ballum }(30 \%) ; \\
\text { Djasiman }(10 \%) ; \\
\text { Cynopteri }(10 \%) ; \\
\text { Tarassovi }(10 \%) ; \\
\text { Hebdomadis }(10 \%)\end{array}$ \\
\hline 2 & Sejroe $(100 \%)$ & Icterohaemorrhagiae (100\%) \\
\hline 3 & Sejroe $(100 \%)$ & Negative \\
\hline 4 & Pomona (100\%) & $\ldots^{\mathrm{a}}$ \\
\hline 5 & $\begin{array}{l}\text { Sejroe }(66.7 \%) ; \\
\text { Hebdomadis }(33.3 \%)\end{array}$ & $\ldots^{a}$ \\
\hline 6 & $\begin{array}{l}\text { Sejroe (50\%); } \\
\text { Hebdomadis (50\%) }\end{array}$ & Negative \\
\hline
\end{tabular}

${ }^{a}$ Absence of sheep 
The serogroups identified in cattle were Sejroe $(36.8 \%)$, Hebdomadis (26.3\%), Australis (10.5\%), Djasiman $(10.5 \%)$, Ballum (5.3\%), Pomona (5.3\%) and Cynopteri (5.3\%) with titers of 100-800 (Table 3). In sheep, the frequent serogroups were Australis (27.3\%), Ballum (27.3\%), Djasiman (18.1\%), Tarassovi $(9.1 \%)$, Icterohaemorrhagiae $(9.1 \%)$, and Cynopteri $(9.1 \%)$ with titers of 100-400 (Table 4).

Table 3: Leptospira sp. serogroups in cattle under semiarid conditions in Northeastern Brazil, with the respective antibody titers

\begin{tabular}{|c|c|c|c|c|c|}
\hline \multirow{2}{*}{ Serogroups } & \multicolumn{4}{|c|}{ Titers } & \multirow{2}{*}{ Total (\%) } \\
\hline & 100 & 200 & 400 & 800 & \\
\hline Sejroe & 1 & 4 & 2 & - & 7 (36.8) \\
\hline Australis & - & 1 & 1 & - & $2(10.5)$ \\
\hline Pomona & - & - & - & 1 & $1(5.3 \%)$ \\
\hline Ballum & 1 & - & - & - & $1(5.3)$ \\
\hline Hebdomadis & 2 & 3 & - & - & 5 (26.3) \\
\hline Cynopteri & - & 1 & - & - & $1(5.3)$ \\
\hline Djasiman & 2 & - & - & - & $2(10.5)$ \\
\hline
\end{tabular}

Table 4: Leptospira sp. serogroups in sheep under semiarid conditions in Northeastern Brazil, with the respective antibody titers

\begin{tabular}{lcccc}
\hline \multirow{2}{*}{ Sorogroups } & \multicolumn{3}{c}{ Titers } & Total $(\%)$ \\
\cline { 2 - 4 } & 100 & 200 & 400 & \\
\hline Australis & - & 2 & 1 & $3(27.3)$ \\
Tarassovi & - & 1 & - & $1(9.1)$ \\
Ballum & 1 & 2 & - & $3(27.3)$ \\
Cynopteri & 1 & - & - & $1(9.1)$ \\
Djasiman & 1 & 1 & - & $2(18.1)$ \\
Icterohaemorrhagiae & - & 1 & - & $1(9.1)$ \\
\hline
\end{tabular}

Despite the animals are under the same climate and management conditions, cattle showed positive serological results at a higher rate, which possibly suggests a higher resistance of sheep to the infection as indicated in previous study (COSTA et al., 2017). Despite this, the seropositivity in sheep was $27.1 \%$, a high percentage considering the results obtained in other surveys conducted in this species in Brazil (AMORIM et al., 2016; COSTA et al., 2016; HIGINO et al., 2010). However, it is noteworthy that the present study was performed on known positive properties, which may have influenced the higher detection of reactive animals.

The frequency of Leptospira sp. seropositivity was high in both cattle and sheep despite the semiarid region being unfavorable for Leptospira survival (FAINE et al., 1999; HASHIMOTO et al., 2012). This finding points out to the existence of alternative transmission routes in the presence of adverse conditions. Recently, several studies have investigated the possibility of male-female venereal transmission in cattle and sheep
(DIRECTOR et al., 2014; LILENBAUM et al., 2008; LOUREIRO et al., 2016; LOUREIRO et al., 2017). Similarly, in a recent study (SILVA et al., 2018) by our research group Leptospira DNA was detected in 55\% (61/111) of tissue samples of genital tract (uterus, ovary, and uterine tubes) collected from sheep slaughtered in the Brazilian semiarid region and in $33.3 \%(8 / 24)$ of vaginal swab samples collected from cattle in a leptospirosis outbreak in Northeastern Brazil (PIMENTA et al., 2018). Therefore, this transmission route might favor the leptospirosis to be endemic in herds (LOUREIRO et al., 2016), justifying the significance of these findings.

The Sejroe serogroup was detected most frequently in the cattle in the present study as reported by other authors (MARQUES et al., 2010; MARTINS; LILENBAUM, 2013; SILVA et al., 2012). This result is expected since cattle are considered capable of adapting to this serogroup (MARTINS et al., 2012; MARTINS; LILENBAUM, 2013). It can be inferred that cattle are acting as important sources of infection within herds, transmitting leptospires by direct contact. These aspects should be considered in the epidemiology and elaboration of control and prevention measures against this serogroup since this transmission is occurring within the same species with low dependence on environmental factors (MARTINS; LILENBAUM, 2017). The Australis and Ballum serogroups were the most frequent in sheep, corroborating the results reported by other authors (AMORIM et al., 2016; AZEVEDO et al., 2004; BENKIRANE et al., 2014; CARVALHO et al., 2011; COSTA et al., 2016). Australis is commonly observed in swine (HAMOND et al., 2015), while domestic rats are the main reservoirs of the serogroup Ballum (BHARTI et al., 2003).

In Property 1, Australis, Ballum, Hebdomadis, and Djasiman serogroups were identified in both cattle and sheep. The highest serological positivity frequencies were observed in both cattle $(70.6 \%)$ and sheep $(70.6 \%)$. It is worth mentioning that among the total number of PCR-positive samples $8(89 \%)$ were from this property. It was verified that there was the practice of consorted rearing of cattle and sheep in Property 1, and it was the only one in which animals were in close contact and grazed in the same place. Thus, it is suggests that, in semiarid conditions, this close contact among species favors the spreading of Leptospira as observed by Escócio et al. (2010) and Genovez et al. (2011) when evaluating the transmission of Leptospira between cattle and sheep in consortia herds and exclusive sheep herds in the state of São Paulo, Southeastern Brazil.

Although it is considered a gold standard diagnostic method, cross-reactive reactions can be observed in MAT, especially in the acute phase of the disease. This is due to some factors: presence of lipopolysaccharides common to serotypes leading to recognition of antigenically similar serovars, presence of non-specific antibodies, animals from endemic areas that may be infected by more than one serovar and recurrent infections that may activate immune memory demonstrating the history of previous exposures, leading to coagglutination in MAT (HAAKE; LEVETT, 2015; CHIRATHAWORN et al., 2014). An example is the cross-reaction between serovars Hardjo and Wolffi, which belong to serogroup Sejroe, having great antigenic similarity (COSTA et al., 1998).

Although serological testing is recommended and recurrent for the diagnosis of leptospirosis, usually infected animals are not 
identified by this technique, especially when infected by strains that exert adaptability relationship with the host (MARTINS; LILENBAUM, 2014). In such cases, the animal does not produce detectable antibodies in the MAT and may be neglected in its diagnosis, as demonstrated in natural and experimental ruminant infections (OTAKA et al., 2012; COSTA et al., 2018; ROCHA et al., 2018). On the other hand, direct detection of the agent by molecular methods becomes an essential tool for detection of the agent in body fluids when the disease is in its chronic phase, and its use associated with MAT is recommended to make the diagnosis reliable (GAMAGE et al., 2011; OTAKA et al., 2012; DIRECTOR et al., 2014; COSTA et al., 2018).

It is known that the influence of the environment is fundamental on the dissemination of leptospirosis among animals (ELLIS, 2015), however in regions where environmental conditions are adverse, such as the semiarid, animal reservoirs become even more important in disease transmission in the region (COSTA et al., 2019). Although on property 1 some cattle and sheep showed seroreactivity to the same serogroups, the most frequent serogroups in each species were distinct, which may indicate different sources of infection, either by their own transmission cycles between members of the same species or by wildlife. Therefore, in this scenario, the best alternatives for prevention and control of leptospirosis in ruminants in the region would be the identification, treatment and isolation of affected animals, as well as effective rodent control. In the specific case of property 1 , a cattle and sheep immunization program would be necessary, justified by the high frequency of seropositive animals and carriers found.

The non-isolation of leptospires from urine probably occurred due to intermittent elimination of leptospires and the possibility that the animals were not eliminating the agent since serology cannot identify animals that are renal carriers (LIBONATI et al., 2017; ROCHA et al., 2017). Other possibilities would be the slow growth rate of the bacteria (ADLER; MOCTEZUMA, 2010) and the contamination of cultures by other microorganisms (RAHELINIRINA et al., 2010).

\section{Conclusion}

In conclusion, in semiarid conditions, transmission between animals of the same species seems to be the main form of Leptospira sp. dissemination in sheep and cattle, however, the role of other domestic and wild animals cannot be discarded. It is also suggested that the practice of consorted rearing of cattle and sheep and their close coexistence facilitates the spread of the agent in rural properties, as well as the existence of alternative transmission routes in the presence of unfavorable environmental conditions for Leptospira sp. survival.

\section{Acknowledgments}

The authors thank the National Council for Scientific and Technological Development (CNPq) for supporting this project (Process number 302222/2016-2).

\section{References}

ADLER, B.; MOCTEZUMA, A.P. Leptospira and leptospirosis. Veterinary Microbiology, v. 140, n. 3-4, p. 287-296, 2010. DOI: 10.1016/j.vetmic.2009.03.012.

ALVES, C.J.; ALCINO, J.F.; FARIAS, A.E.M.; HIGINO, S.S.S.; SANTOS, F.A.; AZEVEDO, S.S.; COSTA, D.F.; SANTOS, C.S.A. B. Caracterização epidemiológica e fatores de risco associados à leptospirose em ovinos deslanados do semiárido brasileiro. Pesquisa Veterinária Brasileira, v. 32, n. 6, p. 523-528, 2012.

AMORIM, R.M.; NASCIMENTO, E.M.; SANTAROSA, B.P.; DANTAS, G.N.; FERREIRA, D.O.L.; GONÇALVES, R.C. Soroprevalência da leptospirose em ovinos da região CentroOeste do estado de São Paulo. Arquivo Brasileiro de Medicina Veterinária e Zootecnia, v. 23, n.2, p. 297-305, 2016.

ANDRADE-LIMA, D. The Caatinga dominium. Revista Brasileira de Botânica, v. 4, p. 149-153, 1981.

AZEVEDO, S.S.; ALVES, C.J.; ANDRADE, J.S.L.; BATISTA, C.S.A.; CLEMENTINO, I.J.; SANTOS, F.A.S. Ocorrência de aglutininas anti-Leptospira em ovinos do estado do Rio Grande do Norte, Brasil. Revista Brasileira de Ciência Veterinária, v. 11, n.3, p. 167-170, 2004. DOI:10.4322/rbcv.2014.371.

AYRES, M.; AYRES JUNIOR, M.; AYRES, D.L.; SANTOS, A.S. Bioestat 5.0 - Aplicações estatísticas nas das ciências biomédicas, Quinta ed. Bélem; Pará, 2007.
BHARTI, A.R.; NALLY, J.E.; RICALDI, J.N.; MATTHIAS, M.A.; DIAZ, M.M.; LOVETT, M.A.; LEVETT, P.N.; GILMAN, R.H.; WILLIG, M.R.; GOTUZZO, E.; VINETZ, J.M. Leptospirosis: a zoonotic disease of global importance. Lancet Infectius Diseases, v. 3, n. 12, p. 757-771, 2003. DOI: 10.1016/S14733099(03)00830-2.

BATISTA, J.S.; RIET-CORREA, F.; TEIXEIRA, M.M.G.; MADRUGA, C.R.; SIMÕES, S.D.V.; MAIA, T.F. Trypanosomiasis by Trypanosoma vivax in cattle in the Brazilian semiarid: description of an outbreak and lesions in the nervous system. Veterinary Parasitology, v. 143, n. 2, p. 174-181, 2007. DOI: 10.1016/j.vetpar.2006.08.017.

BENKIRANE, A.; NOURY, S.; HARTSKEER, R.A.; GORIS, M.G.A.; AHMED, A.; NALLY, J.E. Preliminary Investigations on the Distribution of Leptospira Serovars in Domestic Animals in Northwest Morocco. Transboundary and Emerging Diseases, v. 63, n. 2, p. 178-184, 2016. DOI: 10.1111/tbed.12252.

CAMPOS, A.P.; MIRANDA, D.F.H.; RODRIGUES, H.W.S.; LUSTOSA, M.S.C.; MARTINS, G.H.C.; MINEIRO, A.L.B.; CASTRO, V.; AZEVEDO, S.S.; SILVA, S.M. M.S. Seroprevalence and risk factors for leptospirosis in cattle, sheep, and goats at consorted rearing from the State of Piauí, northeastern Brazil. Tropical Animal Health and Production, v. 49, n. 5, p. 899-907, 2017. DOI: $10.1007 / \mathrm{s} 11250-017-1255-2$.

CARVALHO, S.M.C.; GONÇALVES, L.M.F.; MACEDO, N.A.; GOTO, H.; SILVA, S.M.M.S.; MINEIRO, A.L.B.B.; KANASHIRO, E.H.Y.; COSTA, F.A.L. Infecção por leptospiras em ovinos e caracterização da resposta inflamatória renal. Pesquisa Veterinária Brasileira, v. 31, n. 8, p. 637-642, 2011. DOI: 10.1590/ S0100 736X2011000800001. 
CHAKRABORTY, S.; MIYAHARA, S.Y.; VILLANUEVA, M.; SAITO, N.G.; GLORIANI, S.A.; YOSHIDA, S. Novel combination of selective agents for isolation of Leptospira species. Microbiology Immunology, v. 55, n. 7, p. 494-501, 2011. DOI: 10.1111/j.13480421.2011.00347.x.

CHIRATHAWORN, C.; INWATTANA, R.; POOVORAWAN, Y. Interpretation of microscopic agglutination test for leptospirosis diagnosis and seroprevalence. Asian Pacific Journal of Tropical Biomedicine, v. 4, n.1, p.162-164, 2014. DOI: 10.12980/ APJTB.4.2014C580.

COSTA, D.F.; FARIA, P.J.A.; NOGUEIRA, D.B.; TOLENTINO, L.H.O.; VIANA, M.P.; SILVA, J.D.; VAZ, A.F.M.; HIGINO, S.S.S.; AZEVEDO, S.S.; ALVES, C.J. influence of breed on the clinical and hemato-biochemical parameters in sheep experimentally infected with Leptospira sp. Heliyon, v. 5, n. 10, e02720, 2019. DOI: 10.1016/j.heliyon.2019.e02720.

COSTA, D.F.; SILVA, M.L.C.R.; MARTINS, G.; DANTAS, A.F.M.; MELO, M.A.; AZEVEDO, S.S.; LILENBAUM, W.; ALVES, C.J. Susceptibility among breeds of sheep experimentally infected with Leptospira interrogans Pomona serogroup. Microbial Pathogenesis, v. 122, p. 79-83, 2018. DOI: 10.1016/j. micpath.2018.06.017.

COSTA, D.F.; SILVA, A.F.; BRASIL, A.W.L.; LOUREIRO, A.P.P.; SANTOS, F.A.; AZEVEDO, S.S.; LILENBAUM, W.; ALVES, C.J. Leptospirosis in native mixed-breed sheep slaughtered in a semiarid region of Brazil. Ciência Rural, v. 47, n. 2, p. 1-6, 2017. DOI: 10.1590/0103-8478cr20160563.

COSTA, D.F.; SILVA, A.F.; FARIAS, A.E.M.; BRASIL, A.W.L.; SANTOS, F.A.; GUILHERME, R.F.G.; AZEVEDO, S.S.; ALVES, C.J. Serological study of the Leptospira spp. infection in sheep and goats slaughtered in the State of Paraíba, semiarid of Northeastern Brazil. Semina: Ciências Agrárias, v. 37, n. 2, p. 819-828, 2016. DOI: 10.5433/1679-0359.2016v37n2p819.

COSTA, M.C.R.; MOREIRA, E.C.; LEITE, R.C.; MARTINS, N.R.S. Avaliação da imunidade cruzada entre Leptospira hardjo e $L$. wolffi. Arquivo Brasileiro de Medicina Veterinária e Zootecnia, v. 50, n. 1, p. 11-17, 1998. http://www.bibliotecadigital.ufmg.br/ dspace/handle/1843/BUOS-8QGLZ4.

DIRECTOR, A.; PENNA, B.; HAMOND, C.; LOUREIRO, A.P.; MARTINS, G.; MEDEIROS, M.A.; LILENBAUM, W. Isolation of Leptospira interrogans Hardjoprajitno from vaginal fluid of a clinically healthy ewe suggests potential for venereal transmission. Journal of Medical Microbiology, v. 63, n. 9, p. 1234-1236, 2014. DOI: 10.1099/jmm.0.065466-0.

ELLIS, W.A. Animal leptospirosis. Current Topics in Microbiology and Immunology, v. 387, p. 99-137, 2015. DOI: 10.1007/978-3662-45059-8_6.

ESCÓCIO, C.; GENOVEZ, M.E.; CASTRO, V.; PIATTI, R.M.; GABRIEL, F.H.L.; CHIEBAO, D.P.; AZEVEDO, S.S.; VIEIRA, S.R.; CHIBA, M. Influência das condições ambientais na transmissão da leptospirose entre criações de ovinos e bovinos da região de Sorocaba, SP. Arquivos do Instituto Biológico, v. 77, n. 3, p. 371 379, 2010.

FAINE, S.; ADLER, B.; BOLIN, C.; PEROLAT, P. Leptospira and leptospirosis. Segunda ed. Melbourne, MediSci, 1999.

GAMAGE, C.D.; KOIZUMI, N.; MUTO, M.; NWAFOR-OKOLI, C.; KURUKURUSURIYA, S.; RAJAPAKSE, J.R.; KULARATNE, S.A.; KANDA, K.; LEE, R.B.; OBAYASHI, Y.; WATANABE, H.; TAMASHIRO, $\mathrm{H}$. Prevalence and carrier status of leptospirosis in smallholder dairy cattle and peridomestic rodents in Kandy, Sri Lanka. Vector-Borne and Zoonotic Diseases, v. 11, n. 8, p. 10411047, 2011. DOI: 10.1089/vbz.2010.0153.
GENOVEZ, M.E.; ESCÓCIO, C.; CASTRO, V.; GABRIEL, F.H.L.; CHIEBAO, D.P.; AZEVEDO, S.S. Fatores de risco associados à infecção pela Leptospira spp. sorovar hardjo em rebanhos exclusivos de ovinos e nos consorciados com bovinos. Arquivos do Instituto Biológico, v. 78, n. 4, p. 587-592, 2011.

HAAKE, D.A.; LEVETT, P.N. Leptospirosis in humans. Current Topics in Microbiology and Immunology, v. 387, p. 65-97, 2015. Doi:10.1007/978-3-662-45059-8_5

HAMOND, C.; MARTINS, G.; LOUREIRO, A.P.; BREMONT, S.; MEDEIROS, M. A.; BOURHY, P.; LILENBAUM, W. First isolation and characterization of Leptospira interrogans serogroup Australis from swine in Brazil. Pesquisa Veterinária Brasileira, v. 35, n. 1, p. 6-8, 2015. DOI: 10.1590/S0100-736X2015000100002.

HASHIMOTO, V.Y.; DIAS, J.A.; SPOHR, K.A.H.; SILVA, M.C.P.; ANDRADE, M. G.B.; MÜLLER, E.E.; FREITAS, J.C. Prevalence and risk factors for Leptospira spp. in cattle herds in the south central region of Paraná state. Pesquisa Veterinária Brasileira, v. 32, n. 2, p. 99-105, 2012. DOI: 10.1590/S0100736X2012000200001.

HERNÁNDEZ-RODRÍGUEZ, P.; DÍAZ, C.A.; DALMAU, E.A.; QUINTERO, G.M. A. Comparison between polymerase chain reaction (PCR) and traditional techniques for the diagnosis of leptospirosis in bovines. Journal of Microbiological Methods, v. 84, n. 1, p. 1-7, 2011. DOI: 10.1016/j.mimet.2010.10.021.

HIGINO, S.S.S.; AZEVEDO, S.S.; ALVES, C.J.; FIGUEIREDO, S.M.; SILVA, M.L. C.R.; BATISTA, C.S.A. Frequência de leptospirose em ovinos abatidos no município de Patos, Paraíba. Arquivos do Instituto Biológico, v. 77, n. 3, p. 525-527, 2010.

HIGINO, S.S.S.; SANTOS, F.A.; COSTA, D.F.; SANTOS, C.S.A.B.; SILVA, M.L.C. R.; ALVES, C.J.; AZEVEDO, S.S. Flocklevel risk factors associated with leptospirosis in dairy goats in a semiarid region of Northeastern Brazil. Preventive Veterinary Medicine, v. 109, n. 1-2, p. 158-161, 2013. DOI: 10.1016/j. prevetmed.2012.09.005.

LIBONATI, H.; PINTO, P.S.; LILENBAUM, W. Seronegativity of bovines face to their own recovered leptospiral isolates. Microbial Pathogenesis, v. 188, p. 101-103, 2017. DOI: 10.1016/j. micpath.2017.05.001.

LILENBAUM, W.; VARGES, R.; BRANDÃO, F.Z.; CORTEZ, A.; DE SOUZA, S.O.; BRANDÃO, P.E.; RICHTZENHAIN, L.J.; VASCONCELLOS, S.A. Detection of Leptospira spp. in semen and vaginal fluids of goats and sheep bypolymerase chain reaction. Theriogenology, v. 69, n. 7, p. 837-842, 2008. DOI: 10.1016/j.theriogenology.2007.10.027.

LOUREIRO, A.P.; MARTINS, G.; NARDUCHE, L.; LIBONATI, H.; LILENBAUM, W. Detecção de Leptospira sp. em muco cervicovaginal de vacas sugere importância do portador vaginal na epidemiologia da leptospirose bovina. Revista de Educação Continuada em Medicina Veterinária e Zootecnia, v. 14, n. 2, p. 93, 2016.

LOUREIRO, A.P.; PESTANA, C.; MEDEIROS, M.A.; LILENBAUM, $W$. High frequency of leptospiral vaginal carriers among slaughtered cows. Animal Reproduction Science, v. 178, p. 50-54, 2017. DOI: 10.1016/j.anireprosci.2017.01.008.

MARQUES, A.E.; ROCHA, W.V.; BRITO, W.M.E.D.; FIORAVANTI, M.C.S.; PARREIRA, I.M.; JAYME, V.D.S. Prevalência de anticorpos anti-Leptospira spp. e aspectos epidemiológicos da infecção em bovinos do Estado de Goiás. Ciência Animal Brasileira, v. 11, n. 3, p. 607-617, 2010. DOI: 10.5216/cab. v11i3.5460. 
MARTINS, G.; LILENBAUM, W. Comments of environmental conditions for the maintenance of Leptospira in tropical scenarios. Current Microbiology, v. 71, n. 5, p. 624-625, 2015.

MARTINS, G.; LILENBAUM, W. Control of bovine leptospirosis: Aspects for consideration in a tropical environment. Research in Veterinary Science, v. 112, p. 156-160, 2017. DOI: 10.1016/j. rvsc.2017.03.021.

MARTINS, G.; LILENBAUM, W. Leptospirosis in cattle: a challenging scenario for the understanding of the epidemiology. Transboundary and Emerging Diseases, v. 61, n. 1, p. 63-71, 2014. DOI: 10.1111/tbed.12233.

MARTINS, G.; LILENBAUM, W. The panorama of animal leptospirosis in Rio de Janeiro, Brazil, regarding the seroepidemiology of the infection in tropical regions. BMC. Veterinary Research, v. 9, p. 237-243, 2013. DOI: 10.1186/17466148-9-237.

MARTINS, G.; PENNA, B.; LILENBAUM, W. Differences between seroreactivity to leptospirosis in dairy and beef cattle from the same herd in Rio de Janeiro, Brazil. Tropical Animal Health and Production, v. 44, n. 3, p. 377-378, 2012. DOI: $10.1007 /$ s11250011-9918-x.

MIRAGLIA, F.; MORAIS, Z.M.; CORTEZ, A.; MELVILLE, P.A.; MARVULLO, M. F.V.; RICHTZENHAIN, L.J.; VISITIN, J.A.; VASCONCELOS, S.A. Comparison of four antibiotics for inactivating leptospires in bull semen diluted in egg yolk extender and experimentally inoculated with Leptospira santarosai serovar Guaricura. Brazilian Journal of Microbiology, v. 34, n. 2, p. 147-151, 2003. DOI: 10.1590/S1517-83822003000200011.

MUGHINI-GRAS, L.; BONFANTI, L.; NATALE, A.; COMIN, A.; FERRONATO, A.; LA GRECA, E.; PATREGNANI, T.; LUCCHESE, L.; MARANGON, S. Application of an integrated outbreak management plan for the control of leptospirosis in dairy cattle herds. Epidemiology and Infection, v. 142, n. 6, p. 1172-1181, 2014. DOI: $10.1017 /$ S0950268813001817.

OIE. Reference laboratory reports activities. Ulster, Northern Ireland, World Organization for Animal Health, 2014. http:// www.oie.int/fileadmin/Home/fr/Our_scientific_expertise/ reflabreports/2014/report_204_2014_Leptospirosis_UNITED_ KINGDOM.pdf (Acessado em 20 de março de 2017).

OTAKA, D.Y.; MARTINS, G.; HAMOND, C.; PENNA, B.; MEDEIROS, M.A.; LILENBAUM, W. Serology and PCR for bovine leptospirosis: herd and individual approaches. Veterinary Record, v. 170 , n. 13 , p. 338,2012 . DOI: http://dx.doi.org/10.1136/ vr. 100490

PEREIRA JUNIOR, L.R.; ANDRADE, A.P.; ARAÚJO, K.D.; SILVA, A.; BARBOSA, A.S.; BARBOSA, F.M. Espécies da Caatinga como alternativa para o desenvolvimento de novos fitofármacos. Floresta. Ambient, v. 21, p. 4, p. 509-520, 2014. DOI: 10.1590/2179-8087.024212.

PIMENTA, C.L.R.M.; BEZERRA, C.S; MORAIS, D.A.; SILVA M.L.C.R.; NOGUEIRA, D.B.; COSTA, D.F.; SANTOS, C.S.A.B.; HIGINO, S.S.S.; ALVES, C.J.; AZEVEDO, S.S. Seroprevalence and predominant serogroups of Leptospira sp. in serological tests of ruminants in northeastern Brazil. Semina: Ciências Agrárias, v. 40, n. 4, p. 1513-1522, 2019.
PIMENTA, C.L.R.M.; CASTRO, V.; CLEMENTINO, I.J.; ALVES, C.J.; FERNANDES, L.G.; BRASIL, A.W.; SANTOS, C.S.A.B.; AZEVEDO, S.S. Leptospirose bovina no Estado da Paraíba: prevalência e fatores de risco associados à ocorrência de propriedades positivas. Pesquisa Veterinária Brasileira, v. 34, n. 4, p. 332-336, 2014. DOI: 10.1590/S0100-736X2014000400006. PIMENTA, C.L.R.M.; COSTA, D.F.; SILVA, M.L.C.R.; PEREIRA, H.D.; JUNIOR, J. P.A.; MALOSSI, C.D.; ULLMAN, L.S.; ALVES, C.J.; AZEVEDO, S.S. Strategies of the control of an outbreak of leptospiral infection in dairy cattle in Northeastern Brazil. Tropical Animal and Health Production, v. 51, n.1, p. 237-241, 2018. DOI: 10.1007/s11250-018-1635-2.

PINTO, P.S.; LIBONATI, H.; PENNA, B.; LILENBAUM, W. A systematic review on the microscopic agglutination test seroepidemiology of bovine leptospirosis in Latin America. Tropical Animal and Health Production, v. 48, n. 2, p. 239-248, 2016. DOI: 10.1007/s11250-015-0954-9.

PINTO, P.S.; PESTANA, C.; MEDEIROS, M.A.; LILENBAUM, W. Plurality of Leptospira strains on slaughtered animals suggest a broader concept of adaptability of leptospires to cattle. Acta Tropica, v. 172, p. 156-159, 2017. DOI: 10.1016/j. actatropica.2017.04.032.

RAHELINIRINA, S.; LÉON, A.; HARSTSKEERL, R.A.; SERTOUR, N.; AHMED, A.; RAHARIMANANA, C.; FERQUEL, E.; GARNIER, M.; CHARTIER, L.; DUPLANTIER, J.M.; RAHALISON, L.; CORNET, M. First isolation and direct evidence for the existence of large small-mammal reservoirs of Leptospira sp. in Madagascar. PLoS One, v. 5, n. 11, p. 1-9, 2010. DOI: 10.1371/ journal.pone.0014111.

ROCHA, B.R.; NARDUCHE, L.; OLIVEIRA, C.S.; MARTINS, G.; LILENBAUM, W. Molecular demonstration of intermittent shedding of Leptospira in cattle and sheep and its implications on control. Ciência Rural, v. 47, n. 8, p. 1-4, 2017. DOI: 10.1590/0103$8478 \mathrm{cr} 20170088$.

SILVA, J.F.; CONCEIÇÃO, W.L.F.; FAGLIARI, J.J.; GIRIO, R.J.S.; DIAS, R.A.; BORBA, M.R.; MATHIAS, L.A. Prevalência e fatores de risco de leptospirose bovina no Estado do Maranhão. Pesquisa Veterinária Brasileira, v. 32, n. 4, p. 303-312, 2012. DOI: 10.1590/S0100-736X2012000400006.

SILVA, A.F.; FARIAS, P.J.A.; SILVA, M.L.C.R.; ARAÚJO JÚNIOR, J.P.; MALOSSI, C.D.; ULLMANN, L.S.; COSTA, D.F.; HIGINO, S.S.S.; AZEVEDO, S.S.; ALVES, C. J. High frequency of genital carriers of Leptospira sp. in sheep slaughtered in the semiarid region of northeastern Brazil. Tropical Animal and Health Production, v. 50, n. 1, 2018. DOI: 10.1007/s11250-018-1657-9. STODDARD, R.A.; GEE, J.E.; WILKINS, P.P.; MCCAUSTLAND, K.; HOFFMASTER, A.R. Detection of pathogenic Leptospira spp. through TaqMan polymerase chain reaction targeting the LipL32 gene. Diagnostic Microbiology and Infectious Disease, v. 64, n. 3, p. 247-255, 2009. DOI: 10.1016/j.diagmicrobio.2009.03.014 